\title{
Isolation of trachoma virus from patients in West Africa
}

\author{
BY J. SOWA AND L. H. COLLIER \\ Medical Research Council Trachoma Research Group, Medical Research \\ Council Laboratories, Fajara, Gambia and The Lister Institute \\ of Preventive Medicine, London, S.W. I
}

(Received 19 October 1959)

\section{INTRODUCTION}

In 1957, T'ang, Chang, Huang \& Wang described the isolation of viruses from the conjunctivae of three trachoma patients in China. These agents, which resemble viruses of the psittacosis-lymphogranuloma group, were isolated by inoculating conjunctival material into the yolk-sacs of 6- to 8-day embryonate eggs. Shortly afterwards, Collier \& Sowa (1958) isolated similar viruses from trachoma patients in the Gambia ; they were identified as the cause of the disease by inoculation of human volunteers (Collier \& Sowa, 1958; Collier, Duke-Elder \& Jones, 1958).

This paper describes an improved technique of virus isolation; by this method virus has been isolated from twenty-four of thirty trachoma patients examined.

\section{SELECTION OF CASES}

The patients used for these studies were villagers from the Kombo districts in the western part of the Gambia. Some of these patients had been previously observed for several months and had suffered from acute conjunctivitis due to infection with Haemophilus and Streptococcus spp. The conjunctivitis was treated with two or three applications of Mystrepton ointment (Glaxo) containing $10 \mathrm{mg}$. streptomycin sulphate and 2000 units sodium penicillin per gram of soft paraffin base. Repeated observations showed that this procedure did not affect the clinical signs of trachoma or the presence of inclusion bodies. Before attempting to isolate virus, all subjects were examined with the slit lamp to confirm the clinical diagnosis.

\section{LABORATORY METHODS}

Conjunctival scrapings. After instillation of $4 \%$ procaine, scrapings were taken from both the upper palpebral conjunctivae with a small metal spatula (Smith, Gilkes \& Sowa, 1958). Part of the material was spread on a slide for microscopic examination; the remainder was suspended with scrapings from the other eye in $1 \mathrm{ml}$. of diluent (see 'Use of antibiotics').

At first, patients were examined in the laboratory so that scrapings could be inoculated into eggs within a short time. It was later found that virus could be isolated with equal facility from scrapings collected in the villages and brought to the laboratory. When this was done the scrapings were packed in ice immediately after collection, and were left there until inoculation into eggs $5-6 \mathrm{hr}$. later. 
Chick embryos. Freshly laid hens' eggs were collected from the native villages and incubated at $37^{\circ} \mathrm{C}$ for 5-9 days before inoculation, after which they were incubated at $35^{\circ} \mathrm{C}$.

Yolk-sac inoculation. In order to break up cell clumps, the suspension of epithelial scrapings was expelled repeatedly from the tuberculin syringe and no. 12 needle used for inoculation. Each of three eggs was then inoculated by Cox's method (Cox, 1938) with $0 \cdot 3 \mathrm{ml}$. of suspension.

Examination of embryos. From the second day after inoculation eggs were candled daily; embryos dying within the first $48 \mathrm{hr}$. were discarded. Those dying later were examined for the presence of virus; surviving embryos were examined just before hatching was due.

The embryo was tipped into a sterile Petri dish and smears were made from a portion of yolk-sac near the umbilicus. These were stained with Giemsa or by Castañeda's method. Aerobic and anaerobic tests for bacterial sterility were made on all embryos.

Serial passages. Yolk-sacs were ground in a glass tissue grinder with $0.85 \%$ saline to make $20 \%$ or $50 \%(\mathrm{w} / \mathrm{v})$ suspensions, which were inoculated in $0.2 \mathrm{ml}$. amounts into six eggs. As a routine, streptomycin was added in the concentration used to treat the original scrapings, although it was repeatedly demonstrated that virus could be passed in the absence of antibiotics.

Examination for conjunctival inclusion bodies. Epithelial scrapings were spread on slides, stained with iodine and examined for inclusions by the method of Gilkes, Smith \& Sowa (1958). The slides were then decolorized in $95 \%$ methyl alcohol and stained with Giemsa-May-Grünwald. Inclusions that had stained with iodine were verified in the Giemsa-stained smear.

\section{RESULTS}

\section{Use of antibiotics}

It was clear from the outset that the main difficulty in isolating virus would be the presence of bacteria in the sample. In our experience bacterial contamination of the eyes in Gambians is considerable, and is particularly heavy at certain seasons of the year. The bacteria most commonly encountered are non-pathogenic corynebacteria. Haemophilus and Streptococcus spp. are often isolated and undergo seasonal variations in incidence. Micrococci and neisseriae (but not gonococci) are also commonly found.

T'ang et al. (1957) found that penicillin, terramycin and aureomycin inhibit the growth of trachoma virus and clinical trials have repeatedly shown its susceptibility to other antibiotics, notably the tetracyclines, and to sulphonamides. However, the Chinese workers found that streptomycin could be used to inhibit bacterial contaminants without affecting viral multiplication. They took swabs from the conjunctiva, extracted them with $1.0 \mathrm{ml}$. of broth saline, and added streptomycin to a final concentration of about $2500 \mu \mathrm{g}$. $/ \mathrm{ml}$. This material was inoculated into six embryos.

A few attempts at isolation were made using the method of 'T'ang et al. (1957), but 
many of the embryos succumbed to bacterial infection. Later, $0.85 \%$ saline containing streptomycin $1000 \mu \mathrm{g} . / \mathrm{ml}$. was substituted for the broth-saline used by T'ang; instead of collecting conjunctival cells on a swab, a scraping was taken from the upper tarsal conjunctiva with a small metal spatula, thus increasing the amount of material obtained. After holding at room temperature (about $30^{\circ} \mathrm{C}$.) for $1 \frac{1}{2}-2 \mathrm{hr}$. the specimen was inoculated into three embryos, each of which thus received $330 \mu \mathrm{g}$. streptomycin. It was then found that the concentration of streptomycin could be raised to $20,000 \mu \mathrm{g} . / \mathrm{ml}$. without affecting the virus or the chick embryos. Each embryo now received $6700 \mu \mathrm{g}$. streptomycin; by this means the number of embryos contaminated by bacteria was greatly reduced (Table 1).

\section{Table 1. The use of streptomycin to inhibit bacterial contamination in eggs}

\begin{tabular}{|c|c|c|c|c|c|c|c|}
\hline $\begin{array}{l}\text { Concen- } \\
\text { tration } \\
\text { of strepto- } \\
\text { mycin in } \\
\text { diluent } \\
(\mu \mathrm{g} . / \mathrm{ml} .)\end{array}$ & Inoculum & $\begin{array}{l}\text { No. } \\
\text { of } \\
\text { speci- } \\
\text { mens }\end{array}$ & $\begin{array}{c}\text { Total } \\
\text { eggs } \\
\text { (first } 3 \\
\text { pas- } \\
\text { sages) }\end{array}$ & $\begin{array}{c}\text { Contaminant } \\
\text { only }\end{array}$ & $\begin{array}{l}\text { Virus } \\
\text { only }\end{array}$ & $\begin{array}{l}\text { Contaminant } \\
\text { and virus }\end{array}$ & Sterile \\
\hline \multirow[t]{2}{*}{1000} & $\begin{array}{l}\text { Trachomatous } \\
\text { material }\end{array}$ & 33 & 312 & $157(50 \%)$ & $104(33 \%)$ & $27(9 \%)$ & $24(8 \%)$ \\
\hline & $\begin{array}{l}\text { Non-trachomatous } \\
\text { material }\end{array}$ & 12 & 130 & $70(54 \%)$ & 0 & 0 & $60(46 \%)$ \\
\hline \multirow[t]{2}{*}{20,000} & $\begin{array}{l}\text { Trachomatous } \\
\text { material }\end{array}$ & 13 & 152 & $5(3 \%)$ & $94(62 \%)$ & $1(1 \%)$ & $52(34 \%)$ \\
\hline & $\begin{array}{l}\text { Non-trachomatous } \\
\text { material }\end{array}$ & 32 & 382 & $22(6 \%)$ & 0 & 0 & $360(94 \%)$ \\
\hline
\end{tabular}

It was observed that in a $25 \%$ suspension of yolk-sac, the virus strain G1 became non-infective in $2 \mathrm{hr}$. at $35^{\circ} \mathrm{C}$, indicating that the virus is rapidly susceptible to storage at temperatures of this order. Accordingly, the scrapings suspended in saline containing streptomycin $20,000 \mu \mathrm{g} . / \mathrm{ml}$. were inoculated into embryos immediately after collection, or were kept on ice when storage for short periods was necessary.

Fungal contamination sometimes occurred and was dealt with by adding Mycostatin (Squibb) to the diluent, $50 \mu \mathrm{g} . / \mathrm{ml}$. Two passages in the presence of Mycostatin were sufficient to eliminate the fungus, so this antibiotic was omitted in subsequent passages.

\section{Clinical and virological observations}

Clinical and virological details of trachoma patients are summarized in Table 2. The patients are grouped according to the stage of disease (MacCallan, 1936). In brief, Trachoma $I$ is the initial stage of generalized subepithelial infiltration with minute follicles. Trachoma II is characterized by increase in number and size of follicles and by papillary hypertrophy. In trachoma III scarring of the conjunctiva begins and the infiltration and follicles regress; this may proceed to trachoma IV, the stage of resolution in which the inflammatory process is completely resolved leaving a greater or lesser degree of conjunctival and corneal 
Table 2. Trachoma patients: clinical and virological data

\begin{tabular}{|c|c|c|c|c|c|c|c|}
\hline $\begin{array}{l}\text { Case } \\
\text { no. }\end{array}$ & Sex & $\begin{array}{c}\text { Age } \\
\text { (years) }\end{array}$ & $\begin{array}{l}\text { Trachoma } \\
\text { stage* }\end{array}$ & $\begin{array}{l}\text { Inclu- } \\
\text { sions }\end{array}$ & $\begin{array}{l}\text { Virus } \\
\text { isola- } \\
\text { tion }\end{array}$ & $\begin{array}{l}\text { Strain } \\
\text { no. }\end{array}$ & $\begin{array}{r}\text { Other ocular } \\
\text { abnormalities }\end{array}$ \\
\hline 36 & F. & 2 & $\mathbf{I}$ & + & + & . & . \\
\hline 38 & F. & 2 & I & + & + & G 18 & . \\
\hline 18 & M. & 8 & I & + & + & G 16 & . \\
\hline 13 & M. & 4 & II & - & + & G 20 & . \\
\hline 7 & M. & 6 & II & + & + & $\mathbf{G 2}$ & . \\
\hline 16 & M. & 6 & II & + & + & G 10 & . \\
\hline 19 & M. & 6 & II & - & - & . & . \\
\hline 26 & F. & 6 & II & + & + & . & . \\
\hline 8 & M. & 7 & II & - & + & G 3 & $\begin{array}{l}\text { Corneal opacity, right } \\
\text { eye }\end{array}$ \\
\hline 12 & F. & 7 & II & + & + & G7 & $\cdot$ \\
\hline 32 & M. & 7 & II & + & + & . & . \\
\hline 35 & M. & 7 & II & - & + & G 17 & . \\
\hline 10 & M. & 8 & II & + & + & G5 & . \\
\hline 14 & M. & 8 & II & + & + & G6 6 & . \\
\hline 22 & M. & 9 & II & - & + & G11 & . \\
\hline 34 & M. & 9 & II & + & + & G 13 & . \\
\hline $\mathbf{l}$ & M. & 10 & II & + & + & G9 9 & $\begin{array}{l}\text { Bacterial conjuncti- } \\
\text { vitis, right and left } \\
\text { eyes }\end{array}$ \\
\hline 15 & F. & 10 & II & + & + & G 8 & Phthisis bulbi \\
\hline 28 & M. & 10 & II & + & + & G12 & . \\
\hline 31 & F. & 10 & II & - & - & & $\cdot$ \\
\hline 9 & F. & 12 & II & + & + & G4 4 & $\begin{array}{l}\text { Corneal opacity, right } \\
\text { and left eyes }\end{array}$ \\
\hline 27 & F. & 22 & II & + & + & . & . \\
\hline 33 & F. & 30 & II & - & + & G 14 & . \\
\hline $\mathbf{5}$ & F. & 10 & III & + & + & G 1 & · \\
\hline 48 & F. & 13 & III & - & + & G 19 & $\cdot$ \\
\hline 17 & F. & 15 & III & - & + & G 15 & $\begin{array}{l}\text { Corneal staphyloma, } \\
\text { right eye }\end{array}$ \\
\hline 49 & F. & 30 & III & - & - & - & $\begin{array}{l}\text { Corneal opacity, right } \\
\text { and left eyes }\end{array}$ \\
\hline 30 & F. & 25 & IV & - & - & . & Entropion \\
\hline 23 & F. & 30 & IV & - & - & . & Entropion \\
\hline 25 & F. & 30 & IV & + & - & . & Entropion \\
\hline
\end{tabular}

damage. Pannus is usually an early feature, and may eventually involve much or all of the cornea. In the Gambia, however, pannus is not a constant finding (Scott, 1945; Gilkes, 1958), and it is noteworthy that in ten of the patients with trachoma II or trachoma III, pannus was minimal or absent.

Case no. 25 was diagnosed as trachoma IV on clinical grounds, but the presence of inclusions indicates that the infective process had not completely resolved.

Virus strains kept for further study are designated by the letter G (Gambia) and a number. Those not so designated were discarded. 
Table 3. Record of virological investigations on thirty patients with clinical trachoma

\begin{tabular}{|c|c|c|c|c|c|c|c|c|c|}
\hline $\begin{array}{l}\text { Jase } \\
\text { no. }\end{array}$ & $\begin{array}{c}\text { Date of } \\
\text { examination }\end{array}$ & $\begin{array}{c}\text { Inclu- } \\
\text { sions }\end{array}$ & $\begin{array}{c}\text { Virus } \\
\text { isolation }\end{array}$ & $\begin{array}{l}\text { Concentration of } \\
\text { streptomycin } \\
\text { in diluent } \\
(\times 1000 \mu \mathrm{g} . / \mathrm{ml} .)\end{array}$ & $\begin{array}{l}\text { Case } \\
\text { no. }\end{array}$ & $\begin{array}{c}\text { Date of } \\
\text { examination }\end{array}$ & $\begin{array}{l}\text { Inclu- } \\
\text { sions }\end{array}$ & $\begin{array}{c}\text { Virus } \\
\text { isolation }\end{array}$ & $\begin{array}{c}\text { Concentration o } \\
\text { streptomycin } \\
\text { in diluent } \\
(\times 1000 \mu \mathrm{g} . / \mathrm{ml} .)\end{array}$ \\
\hline 36 & 16. iv. 58 & + & + & 20 & 14 & 5. ii. 58 & + & + & 1 \\
\hline 38 & 24. iv. 58 & + & + & 20 & 22 & 18. x. 57 & - & N.D. & \\
\hline 18 & $\begin{array}{l}\text { 15. xi. } 57 \\
\text { 14. ii. } 58 \\
\text { 16. iv. } 58 \\
7 . \text { i. } 59\end{array}$ & $\begin{array}{l}+ \\
\dot{+} \\
+\end{array}$ & $\begin{array}{l}\text { N.D. } \\
+ \\
+ \\
+\end{array}$ & $\begin{array}{r}i \\
20 \\
20\end{array}$ & 34 & $\begin{array}{l}\text { 27. vii. } 57 \\
\text { 10. iv. } 58 \\
\text { 18. iv. } 58\end{array}$ & $\bar{t}$ & $\begin{array}{l}+ \\
\text { N.D. } \\
+ \\
\text { N.D. }\end{array}$ & 20 \\
\hline 13 & $\begin{array}{r}\text { 5. ii. } 58 \\
\text { 15. v. } 58\end{array}$ & - & $\begin{array}{l}-\{1)^{*} \\
+\end{array}$ & $\begin{array}{r}1 \\
20\end{array}$ & l & $\begin{array}{l}\text { 31. vii. } 57 \\
20 . \text { xi. } 57\end{array}$ & + & $\begin{array}{l}\text { N.D. } \\
\text { N.D. }\end{array}$ & $\dot{r}$ \\
\hline 7 & $\begin{array}{l}\text { 31. vii. } 57 \\
27 . \times \text { i. } 57\end{array}$ & $\begin{array}{l}+ \\
+\end{array}$ & . & - & & $\begin{array}{l}\text { 27. xi. } 57 \\
\text { 12. ii. } 58\end{array}$ & $\begin{array}{c}+ \\
\text { N.D. }\end{array}$ & $\begin{array}{l}-(3) \\
+\end{array}$ & $\begin{array}{l}1 \\
1\end{array}$ \\
\hline & 6. i. 58 & + & $-(1)$ & 1 & 15 & 12. ii. 58 & + & + & 1 \\
\hline & $\begin{array}{r}9 . \text { i. } 58 \\
\text { 16. i. } 58\end{array}$ & $\begin{array}{l}\text { N.D. } \\
\text { N.D. }\end{array}$ & $\begin{array}{l}-(1) \\
+\end{array}$ & $\begin{array}{l}1 \\
1\end{array}$ & 28 & $\begin{array}{l}\text { 29. vii. } 57 \\
\text { 19. iii. } 58\end{array}$ & + & $\begin{array}{l}\text { N.D. } \\
-(1)\end{array}$ & i \\
\hline 16 & $\begin{array}{l}\text { 28. viii. } 57 \\
14 . \text { ii } 58\end{array}$ & + & N.D. & 1 & & 31. iii. 58 & N.D. & + & 1 \\
\hline 19 & $\begin{array}{r}\text { 14. ii. } 58 \\
\text { 5. vi. } 58\end{array}$ & - & $\begin{array}{l}-(1) \\
-(3)\end{array}$ & $\begin{array}{r}1 \\
20\end{array}$ & 31 & $\begin{array}{l}26 . \text { iii. } 58 \\
29 . \text { iii. } 58\end{array}$ & - & $\begin{array}{l}-(4) \\
\text { N.D. }\end{array}$ & $\begin{array}{l}1 \\
\cdot\end{array}$ \\
\hline 26 & $\begin{array}{l}5 . \text { vi. } 58 \\
\text { 18. x. } 57 \\
\text { 22. ii. } 58\end{array}$ & $\begin{array}{l}- \\
+ \\
+\end{array}$ & $\begin{array}{l}\text { N.D. } \\
+\end{array}$ & i & 9 & $\begin{array}{l}\text { 9. x. } 58 \\
\text { 30. xi. } 57 \\
11 . \text { i. } 58\end{array}$ & $\begin{array}{c}+ \\
+ \\
\text { N.D. }\end{array}$ & $\begin{array}{l}\text { N.D. } \\
-(3) \\
-(2)\end{array}$ & i \\
\hline 8 & $\begin{array}{l}\text { 31. vii. } 57 \\
\text { 6.i. } 58\end{array}$ & - & $\begin{array}{l}\text { N.D. } \\
-(1)\end{array}$ & i & 27 & $\begin{array}{l}\text { 14. i. } 58 \\
\text { 11. iii. } 58\end{array}$ & $\begin{array}{l}\text { N.D. } \\
+\end{array}$ & $\begin{array}{l}+ \\
+\end{array}$ & $\begin{array}{l}1 \\
1\end{array}$ \\
\hline & $\begin{array}{r}9 . \text { i. } 58 \\
16 . \text { i. } 58\end{array}$ & $\begin{array}{l}\text { N.D. } \\
\text { N.D. }\end{array}$ & $\begin{array}{l}-(1) \\
+\end{array}$ & 1 & 33 & $\begin{array}{l}\text { 10. iv. } 58 \\
\text { 7. v. } 58\end{array}$ & - & $\stackrel{+}{\text { N.D. }}$ & 20 \\
\hline 12 & $\begin{array}{l}\text { 27. xi. } 57 \\
\text { 12. ii. } 58\end{array}$ & $\stackrel{+}{+}$ & $\begin{array}{l}\text { N.D. } \\
+\end{array}$ & 1 & 5 & $\begin{array}{l}\text { 31. vii. } 57 \\
\text { 27. xi. } 57\end{array}$ & $\overline{+}$ & $\begin{array}{l}\text { N.D. } \\
+\end{array}$ & 1 \\
\hline 32 & 27. vii. 58 & + & N.D. & & 48 & 15. v. 58 & - & + & 20 \\
\hline 35 & 26. iii. 58 & + & + & 1 & 17 & $\begin{array}{l}\text { 14. ii. } 58 \\
\text { 16. iv. } 58\end{array}$ & $\begin{array}{l}\text { N.D. } \\
-\end{array}$ & $\begin{array}{l}-(4) \\
+\end{array}$ & $\begin{array}{r}1 \\
20\end{array}$ \\
\hline & $\begin{array}{c}29 . \text { v. } 58 \\
7 . \text { i. } 59\end{array}$ & - & $\begin{array}{l}\text { N.D. } \\
+\end{array}$ & 20 & $\begin{array}{l}49 \\
30\end{array}$ & $\begin{array}{l}\text { 21. v. } 58 \\
\text { 26. iii. } 58\end{array}$ & $\begin{array}{l}- \\
-\end{array}$ & $\begin{array}{l}-(2) \\
-(2)\end{array}$ & $\begin{array}{r}20 \\
1\end{array}$ \\
\hline 10 & $\begin{array}{l}\text { 31. vii. } 57 \\
27 . \text { xi. } 57 \\
\text { 21. i. } 58 \\
\text { 29. i. } 58\end{array}$ & $\begin{array}{l}+ \\
+ \\
+ \\
\text { N.D. }\end{array}$ & $\begin{array}{l}\text { N.D. } \\
-(8) \\
-(1) \\
+\end{array}$ & $\begin{array}{l}1 \\
1 \\
1\end{array}$ & 25 & $\begin{array}{l}\text { 22. ii. } 58 \\
\text { 18. x. } 57 \\
22 . \text { ii. } 58\end{array}$ & $\begin{array}{l}- \\
- \\
+\end{array}$ & $\begin{array}{l}-(1) \\
\text { N.D. } \\
-(2)\end{array}$ & i \\
\hline
\end{tabular}

Figures in parentheses after negative isolation results indicate number of negative egg passages, including primary inoculation. N.D.= not done.

Table 3 is a record of the virological investigations, showing the number of examinations of each patient, the intervals between them and the concentration of streptomycin used to treat the scrapings. On thirty subjects, fifty-three examinations for inclusions and forty-six attempts at virus isolation were made. The results are summarized in Tables 4-6. Table 4 shows that virus is more readily detected by embryo inoculation than by finding conjunctival inclusions. Table 5 shows that in fifteen of eighteen inclusion-positive patients, inclusions were found 
at first examination; it is therefore unlikely that the number of inclusion-positive patients in this series would have been substantially increased by further examinations. Five patients failing to yield virus by embryo inoculation could only be tested once before concluding this investigation. The same consideration applies to them, since virus isolation was usually accomplished at the first attempt (Table 5). Table 6 summarizes the results obtained with different concentrations of streptomycin.

Table 4. Summary of virological findings in patients with clinical trachoma

$\begin{array}{lccc} & \text { Inclusion } & \text { Inclusion } & \\ \text { positive } & \text { negative } & \text { Totals } \\ \text { Isolation positive } & 17 & 7 & 24(80 \%) \\ \text { Isolation negative } & 1 & 5 & 6(20 \%) \\ \quad \text { Totals } & 18(60 \%) & 12(40 \%) & 30\end{array}$

Of twenty-five control patients all (100\%) were inclusion and isolation negative.

Table 5. Finding of inclusions and isolation of virus from trachoma patients

\begin{tabular}{lr} 
& $\begin{array}{r}\text { No. of } \\
\text { patients }\end{array}$ \\
Inclusions first found at lst attempt & 15 \\
Inclusions first found at 2nd attempt & 3 \\
\multicolumn{1}{c}{ Total } & 18 \\
Virus first isolated at Ist attempt & 16 \\
Virus first isolated at 2nd attempt & 4 \\
Virus first isolated at 3rd attempt & 4 \\
\multicolumn{2}{c}{ Total } \\
\end{tabular}

Table 6. Summary of attempts made to isolate virus from thirty trachoma patients, using different concentrations of streptomycin

Concentration of
streptomycin in
diluent $(\mu \mathrm{g} / \mathrm{ml}$.
1,000 or less
20,000
Totals

\begin{tabular}{ccc}
\multicolumn{2}{c}{ Result } & \\
positive & negative & Totals \\
16 & 17 & 33 \\
11 & 2 & 13 \\
27 & 19 & 46
\end{tabular}

It is noteworthy that, with one exception, virus when present was always isolated in the embryos inoculated with the original scrapings. The embryos inoculated on 14 February 1958 with scrapings from case no. 18 failed to show virus, which appeared in the next passage.

\section{Control subjects}

The non-trachomatous control group consisted of twenty-five subjects; of these three were in the age-group 1-5 years, ten in the group 6-9 years, nine in the group 10-19 years and three in the group 20-40 years. 
Twenty-two of these subjects were examined for the presence of inclusions and cultivable virus on one occasion, and the remaining three on two occasions. Five attempts at isolation were made using streptomycin $1000 \mu \mathrm{g}$., and twenty-three attempts with a concentration of $20,000 \mu \mathrm{g} . / \mathrm{ml}$. At least one, and usually two or three, blind passages were made after the original inoculation into chick embryos. Inclusions were not found in any of these subjects, and from none could virus be isolated by embryo inoculation.

Effects on chick embryos

Properties of the viruses

The virus did not always kill the embryos. Not infrequently, embryos of the same age receiving similar inocula died within 3 or 4 days of inoculation, whereas others survived to the time of hatching. In some instances only those dying 5-7 days after inoculation contained virus and those dying later were sterile. More often embryos dying up to 5 days after inoculation were apparently uninfected and those surviving longer contained numerous elementary bodies. Virus was not found in embryos dying in less than 3 days. Embryos 5-6 days old at time of inoculation survived infection rather longer than did 8- or 9-day embryos. Furthermore, freshly isolated virus seemed less virulent than the same strain after a few passages. The assumption that this resulted from adaptation and faster multiplication of the virus has not yet been verified experimentally. Accurate titrations are difficult because of the variability described above, which was not confined to any particular strain. Some examples are given in Table 7.

Most embryos dying of viral infection had petechial haemorrhages in the skin and congestion of the vasculature of the limbs. The liver and kidneys were congested, but the other organs were normal to the naked eye. We confirmed T'ang's (1957) findings that the yolk was less viscous than in uninfected embryos of the same age and that the membrane was thinner and more friable. These features, although never present in sterile control eggs, were also associated with bacterial infections and cannot, therefore, be considered as specific responses to trachoma virus.

\section{Morphology}

The twenty-four viruses isolated all induced the formation of elementary bodies (Pl. 1), identical in morphology and staining characteristics with those already described (Collier \& Sowa, 1958). Two strains (G16 and G17) differed from the others in inducing the formation of compact aggregates of virus particles in addition to the usual free elementary bodies. These structures appeared on first isolation, and were observed throughout subsequent passages. Both strains were again isolated from patients nos. 18 and 35 several months after the original isolations and both retained their capacity for producing these aggregates. These bodies are about $10-20 \mu$ in diameter and stain intensely with Giemsa. With Castañeda or with light Giemsa staining they appear as aggregates of elementary bodies surrounding clear vacuoles, which may be single, multiple, or perhaps multilocular (Pl. 2a). They stain dark brown or black with Lugol's iodine. 
Table 7. Lethal effect on chick embryos of five strains of trachoma virus

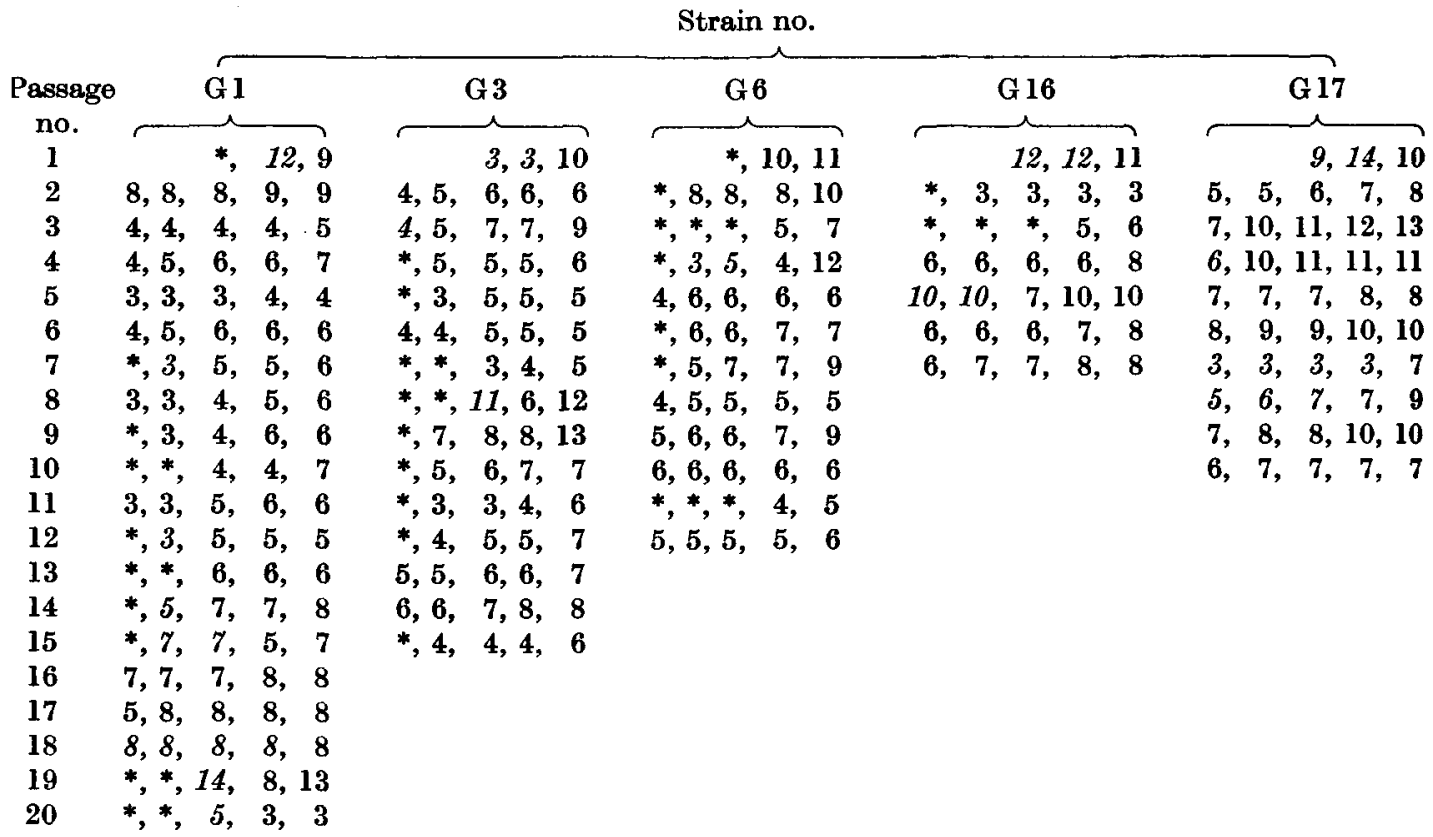

Figures represent number of days from inoculation to death of embryo. Those not in italics indicate specific death due to viral infection. Italicized figures indicate that no virus was found. Embryos surviving longer than 11 days after inoculation were killed on the day shown.

* Indicates non-specific death within $48 \mathrm{hr}$. of inoculation.

Very rapid exposure (3 sec.) colours the vacuole a deep coppery brown; the surrounding mass of virus particles stains more lightly. A number of attempts were made to remove the iodine-staining property by digestion with saliva. Smears of infected yolk-sac were treated at $37^{\circ} \mathrm{C}$. with saliva diluted $1 / 2$ in normal saline, for periods up to $20 \mathrm{hr}$. They were then stained with iodine, and their appearance compared with smears treated similarly with boiled saliva. It was not possible to destroy the iodine-staining property completely, but it seemed that some of the aggregates treated with fresh saliva stained less intensely than the control material (PI. 2b,c). When the aggregates are treated with periodic acid for $5 \mathrm{~min}$. and then with Schiff's reagent, the surrounding 'shell' of virus stains red, and the vacuoles deep reddish purple (Pl. 2d). The iodine-staining property is, however, still retained, but can be completely abolished by treatment with periodic acid at room temperature for $6 \mathrm{hr}$.

In sections of yolk-sac infected with strain G 17, the aggregates lie in the cytoplasm of the endodermal cells lining the sac. They can be clearly distinguished from the unorganized elementary bodies that are also present in these cells (Pl. 3a,b).

These findings indicate that during the growth of some strains of trachoma virus, organized aggregates of virus develop embedded in a matrix surrounding a vacuole. The matrix is comparatively resistant to penetration by ptyalin and 
periodic acid; it may contain some carbohydrate. The vacuoles contain a carbohydrate, probably glycogen.

The significance of these findings is not yet apparent, but they are interesting because of the presence of glycogen in the matrices of conjunctival inclusions (Rice, 1936).

It is worthy of note that strain G 17 has been identified as a trachoma virus by inoculating a human volunteer (Collier, Duke-Elder \& Jones, 1960).

\section{DISCUSSION}

By treating conjunctival scrapings with streptomycin in saline, and inoculating them into the chick embryo yolk-sac, virus was isolated from twenty-four of thirty patients with trachoma.

Taken in conjunction with the successful human inoculation experiment already reported (Collier et al. 1958), the evidence for the aetiological role of the elementary bodies described seems conclusive. In this series, inclusions were found in $60 \%$ of the patients; the percentage in whom a diagnosis could be made on virological grounds is increased to $83.3 \%$ when the results of isolations in eggs are also considered. It is also noteworthy that only one patient in whom inclusions were found failed to yield virus by egg inoculation.

The results obtained indicate the value of using a high concentration of streptomycin when treating conjunctival material before inoculation. They also show that when virus is isolated it can almost always be detected in the yolk-sacs inoculated with the conjunctival scrapings; if virus is not found in these embryos, it is not worth making more than one further passage.

In no instance could virus be isolated from non-trachomatous, inclusionnegative subjects. This suggests that the carrier state is rare or non-existent.

It may reasonably be expected that the virus isolation method will become increasingly important in the diagnosis of trachoma, in assessing the influence of therapy, and in tests of cure. It will also be valuable in elucidating the relationship between clinical signs and the presence of virus at various stages of the disease, and in determining whether the clinical syndrome known as trachoma is invariably due to infection by the same agent.

The methods described in this paper are now being used in a detailed study of trachoma in a Gambian village community. It is hoped that the results obtained will help to clarify some of these problems.

\section{SUMMARY}

1. By inoculating conjunctival scrapings into the chick embryo yolk-sac trachoma virus was isolated from twenty-four of thirty patients, whereas inclusions were demonstrated in only eighteen of them.

2. Bacterial contamination of the chick embryos can be greatly reduced by treating the scrapings with streptomycin $20,000 \mu \mathrm{g} . / \mathrm{ml}$.

3. In twenty-four of twenty-five isolations, virus was first detected in embryos inoculated directly with conjunctival material. 
4. The viruses usually kill the chick embryos, which may show haemorrhagic lesions, but it is not unusual for embryos to survive a large inoculum.

5. The viruses isolated all appear in the chick embryo yolk sac as elementary bodies similar to other members of the psittacosis-lymphogranuloma group. Of the twenty-four strains, two also induced the formation of compact aggregates of elementary bodies containing a carbohydrate, probably glycogen.

6. It is anticipated that this method of isolation will be useful in studying the virology and epidemiology of trachoma, in assessing the influence of treatment, and as a test of cure.

We are deeply indebted to Dr I. A. McGregor for all the facilities made available to us at the M.R.C. Laboratories in the Gambia. Our thanks are also due to the medical officers and sisters at the research ward for their kindness and unfailing co-operation in the care of those trachomatous patients who had to be hospitalized. The excellent technical assistance of Miss A. M. Fischer is gratefully acknowledged.

\section{REFERENCES}

Colliter, L. H., DUke-Elder, S. \& Jones, B. R. (1958). Brit. J. Ophthal. 42, 705.

Collier, L. H., Duke-Eldoer, S. \& Jones, B. R. (1960). Brit. J. Ophthal. 44.

Coluner, L. H. \& SowA, J. (1958). The Lancet, i, 993.

Cox, H. R. (1938). Publ. Hith Rep., Wash., 53, 2241.

GחKES, M. J. (1958). Trans. ophthal. Soc. U.K. 78, 227.

GrKes, M. J., Sмтth, C. H. \& SowA, J. (1958). Brit. J. Ophthal. 42, 473.

MacCallan, A. F. (1936). Trachoma. London: Butterworth and Co.

Rice, C. E. (1936). Amer. J. Ophthal. 19, 1.

ScOTT, J. G. (1945). Brit. J. Ophthal. 29, 244.

SmTth, C. H., GILKES, M. J. \& Sowa, J. (1958). Brit. J. Ophthal. 42, 461.

T'ang, F. F., Chang, H. L., Huang, Y. T. \& Wang, K. C. (1957). Chin. med. J., 75, 429.

\section{EXPLANATION OF PLATES}

\section{Plate 1}

Smear of yolk sac infected with trachoma virus, strain G 1, 24th yolk-sac passage, showing elementary bodies surrounding a nucleated erythrocyte. Stained Giemsa-May-Grünwald. $(\times 1470)$.

\section{Plate 2}

Aggregates of virus in smears of yolk-sac infected with strain G17 virus, 39th yolksac passage. $\times 1230 .($ a) Stained Giemsa-May-Grünwald. Vacuolated aggregate, focus adjusted to show elementary bodies overlying two vacuoles. (b) Treated with boiled saliva for $20 \mathrm{hr}$. at $37^{\circ} \mathrm{C}$., then stained with iodine. The vacuoles stain more intensely than the surrounding 'shell' of elementary bodies. (c) Treated with fresh saliva for $20 \mathrm{hr}$. at $37^{\circ} \mathrm{C}$., then stained with iodine. The vacuoles still stain intensely but some of the surrounding iodine-staining material has been digested. (d) Treated with periodic acid for 5 min. at room temperature, followed by Schiff's reagent. The vacuoles stained a deep reddish purple.

\section{Plate 3}

Section of yolk-sac infected with trachoma virus, strain GI7, 18th yolk-sac passage. Stained Giemsa. (a) $\times 290$. At the left are haemopoietic cells in a villous process. The outlines of the large endodermal yolk-cells are seen at the right; some contain deeply stained masses of virus. (b) $\times 1120$. $A, A^{\prime}$, deeply stained masses of elementary bodies, $B$, vacuolated aggregate (the vacuole has taken up the stain in section, and is surrounded by elementary bodies), $C$, unorganized mass of elementary bodies. 


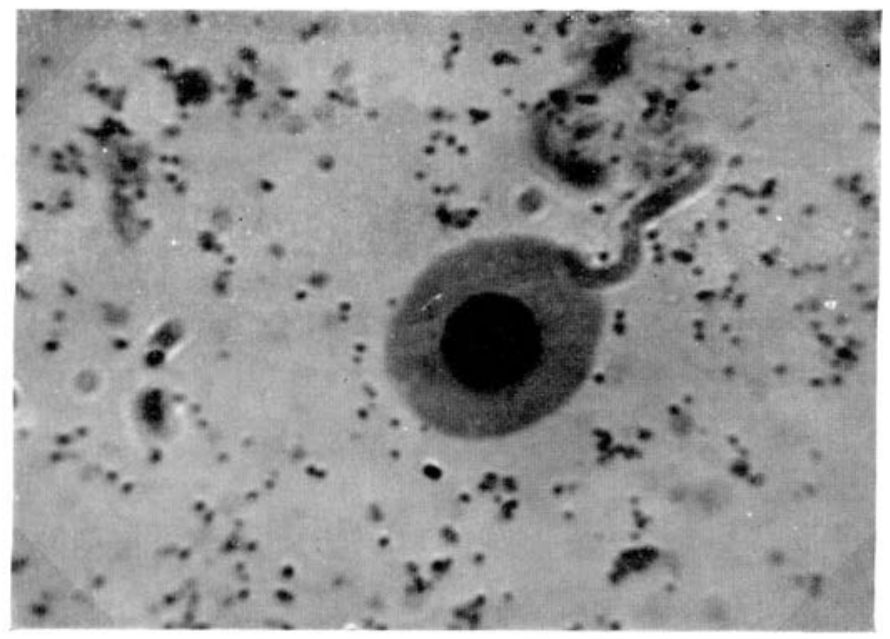




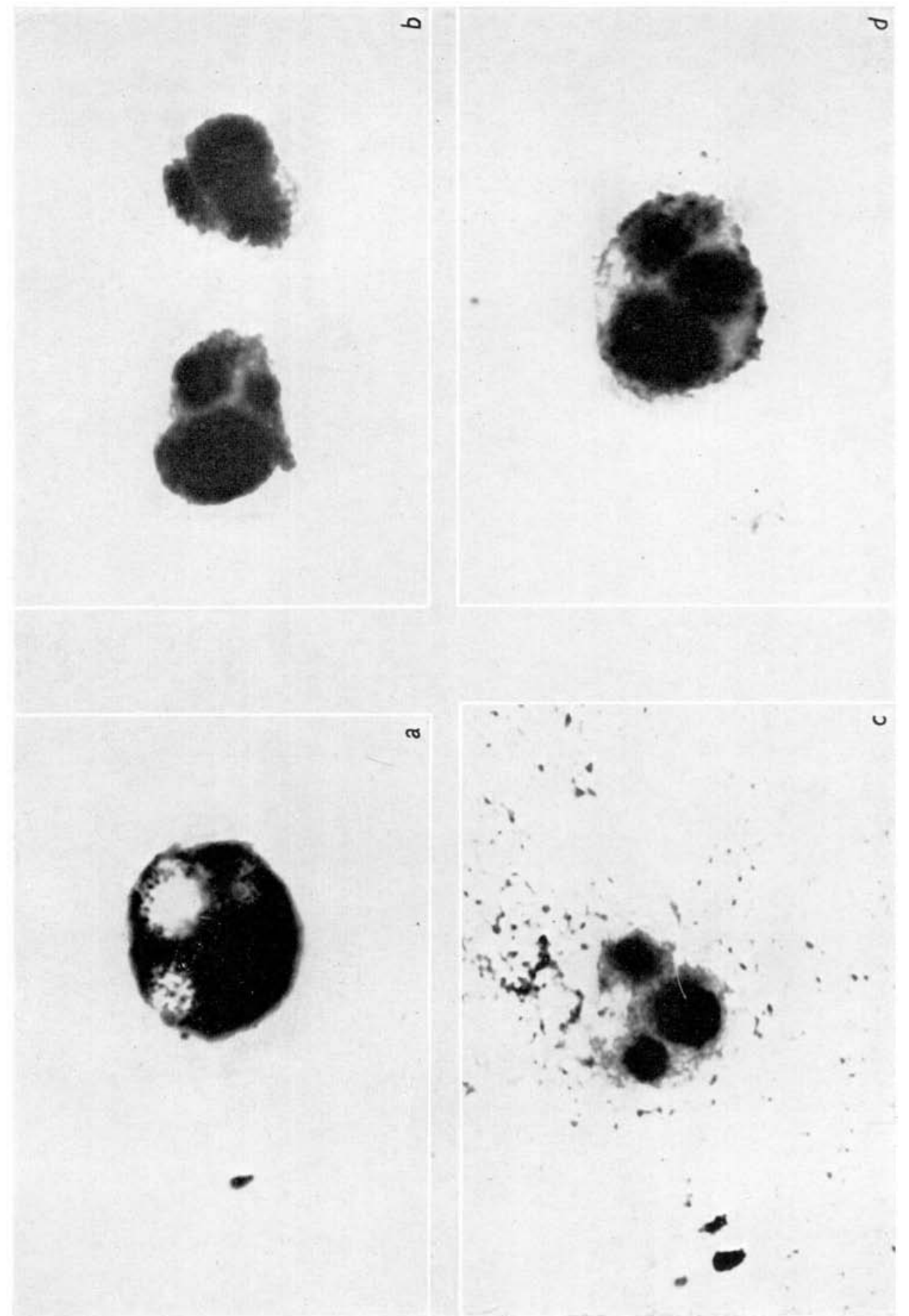

J. SOWA AND L. H COLLIER 

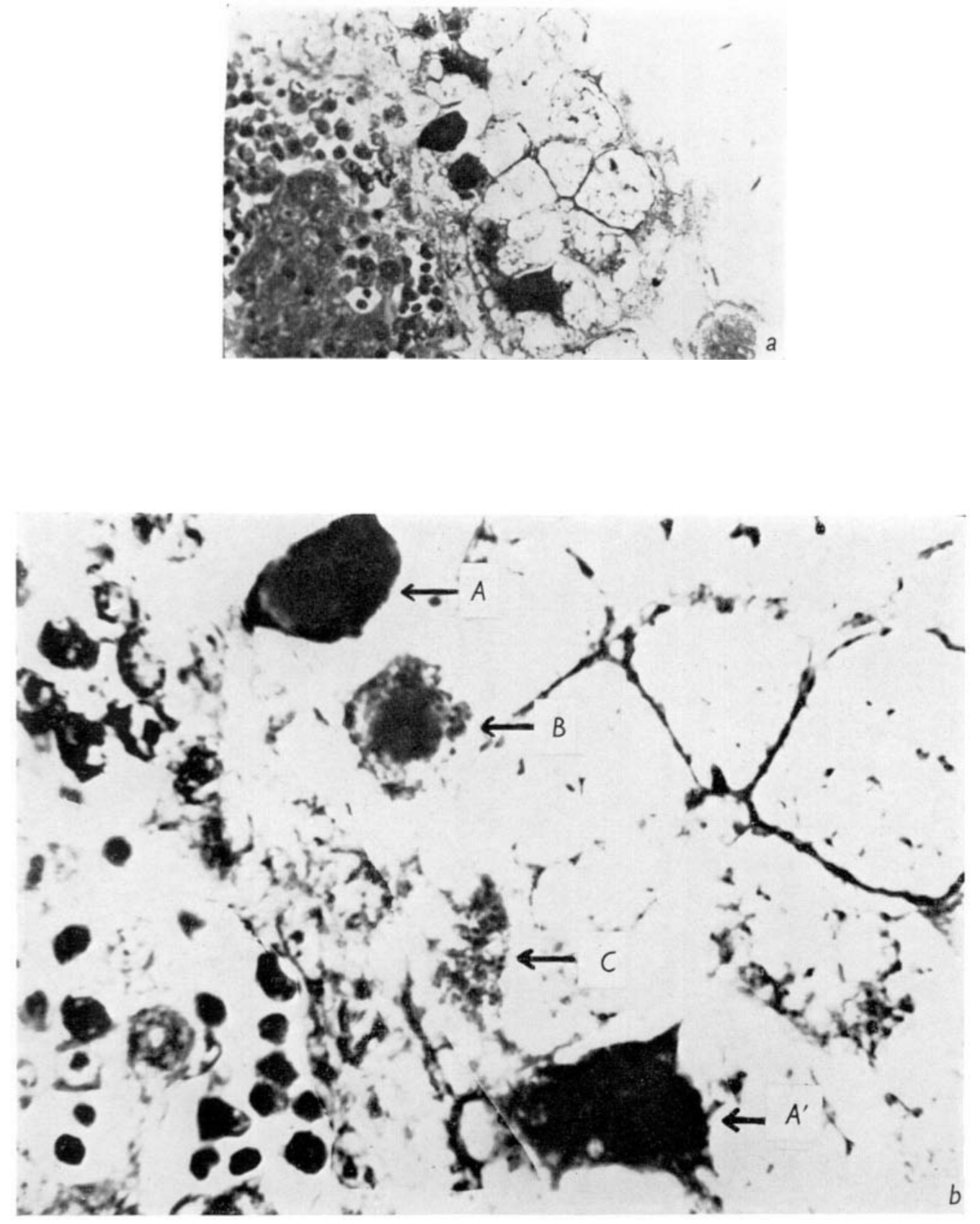